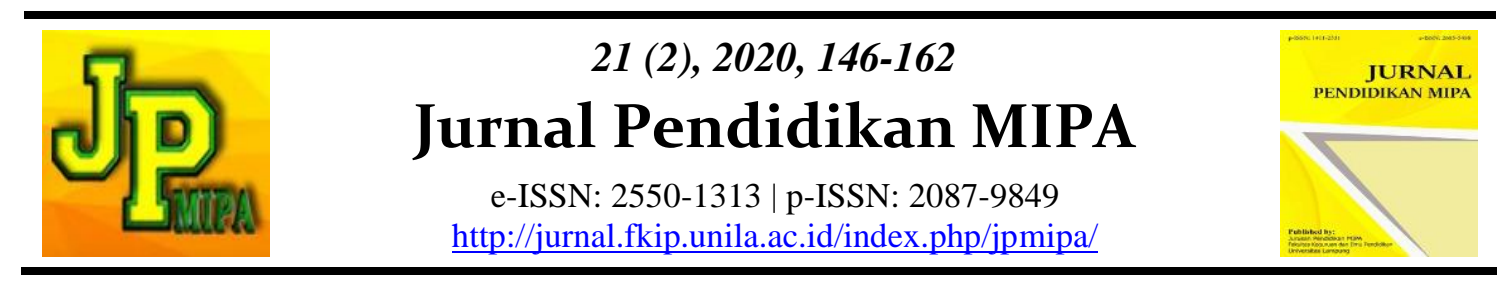

\title{
Teaching Science in The New Normal: Understanding The Experiences of Junior High School Science Teachers
}

\author{
Gilbert Santos Arrieta $^{1,2}$, Jenalyn Cabana Dancel ${ }^{2}$, Mark Jayson Pascua Agbisit ${ }^{2}$ \\ ${ }^{1}$ College of Graduate Studies and Teacher Education Research, Philippine Normal University, Philippines \\ ${ }^{2}$ Department of Junior High School, Don Bosco Technical Institute, Philippines
}

\begin{abstract}
The Covid-19 pandemic has taken aback everyone that led to living unexpectedly in an environment called the new normal. One of the sectors seriously affected by this health crisis is education. With no face-to-face classes until a vaccine has been discovered, the Department of Education-Philippines (DepEd) believed that education should continue in school year 2020-2021 through online and other alternative modalities. The teachers in a private sectarian school in Manila began preparing as early as June 2020 leading to the creation of a learning continuity plan. One of the subjects in the junior high school seriously affected in doing online teaching and learning is Science. This study aims to explore and understand the experiences and challenges of the junior high school Science teachers after one term or almost three months of teaching in the new normal. The study found out that Science teachers were prepared and the curriculum was modified. Instructional materials were enhanced and various challenges were met like student discipline, delivery and execution of learning tasks, limited time for the implementation of the competencies, and student participation.
\end{abstract}

Keywords: teaching science online, challenges of online teaching, science teachers creativity, initiatives and opportunities.

Abstrak: Pandemi Covid-19 mengejutkan semua orang yang menyebabkan hidup di lingkungan tak wajar yang disebut kehidupan normal baru. Salah satu sektor yang terkena dampak serius dari krisis kesehatan ini adalah pendidikan. Tanpa kelas tatap muka hingga vaksin ditemukan, Departemen Pendidikan-Filipina (DepEd) percaya bahwa pendidikan harus dilanjutkan pada tahun ajaran 2020-2021 melalui online dan modalitas alternatif lainnya. Para guru di sekolah swasta di Manila mulai bersiap sejak Juni 2020 yang mengarah pada pembuatan rencana pembelajaran berkesinambungan. Salah satu mata pelajaran di sekolah menengah pertama yang terkena dampak serius dalam melakukan pembelajaran online adalah IPA. Penelitian ini bertujuan untuk menggali dan memahami pengalaman dan tantangan para guru IPA SMP setelah satu semester atau hampir tiga bulan mengajar di normal baru. Studi tersebut menemukan bahwa guru Sains telah disiapkan dan kurikulum telah dimodifikasi. Materi pembelajaran ditingkatkan dan berbagai tantangan ditemui seperti kedisiplinan siswa, penyampaian dan pelaksanaan tugas pembelajaran, waktu yang terbatas untuk pelaksanaan kompetensi, dan partisipasi siswa.

Kata kunci: mengajar sains secara online, tantangan pengajaran online, kreativitas guru sains, inisiatif dan peluang.

Gilbert Santos Arrieta et al.

Email: arrieta.gs@pnu.edu.ph
DOI: http://dx.doi.org/10.23960/jpmipa/v21i2.pp146-162

Received: 09 November 2020

Accepted: 11 December 2020 


\section{INTRODUCTION}

One of the most awaited activities during the year is the opening of classes. Children, teenagers, and even young adults are excited to go back to school after a twomonth vacation. It is in school where their interests, knowledge, and skills are honed, and friendship begins. School life prepares every student to a bigger and challenging life particularly in pursuing one's career. As a student takes another step up the staircase, subjects are added in his studies. This is to make his academic and character formation more holistic and in-depth. From grade school to senior high school, Science and Mathematics are the constant subjects that can be found. Considered as the two most challenging but interesting subjects, lessons become more difficult as one progresses to the next level. Teachers are also challenged to make the Science and Math lessons interesting and engaging considering that the subjects are difficult by nature.

Between Math and Science, it is Science that requires laboratory work. Students are drawn more to Science because it involves a "real" application of theories learned in the classroom. The nature of science education involves students in scientific investigation. Scientific investigation includes the way thinking, attitude, and steps scientific activities to obtain products and knowledge of science. Students should be able to integrate between skills, knowledge and attitudes, to develop knowledge of conceptual understanding better. One of the most important basic skills in scientific inquiry is the skill of the science process. Scientific process skills are a set of skills used in conducting scientific activities, producing and using scientific information, and problem solving. Such skills can be a character in student's self if they have the opportunity to do so in either learning or laboratory activities. The opportunity can be given to students if the learning environment is arranged in such a way that they can engage in science activities to improve their science process skills (Safaah, Muslim, \& Liliawati, 2017).

Science education is one of the most important subjects in school due to its relevance to students' lives and the universally applicable problem-solving and critical thinking skills it uses and develops. These are lifelong skills that allow students to generate ideas, weigh decisions intelligently and even understand the evidence behind public policy-making. Teaching technological literacy, critical thinking and problemsolving through science education gives students the skills and knowledge they need to succeed in school and beyond.

Science education aims to develop scientific literacy among learners that will prepare them to be informed and participative citizens who are able to make judgments and decisions regarding applications of scientific knowledge that may have social, health, or environmental impacts. The science curriculum recognizes the place of science and technology in everyday human affairs. It integrates science and technology in the social, economic, personal and ethical aspects of life. The science curriculum promotes a strong link between science and technology, including indigenous technology, thus preserving our country's cultural heritage. The K to 12 science curriculum is learner-centered and inquiry-based, emphasizing the use of evidence in constructing explanations. Concepts and skills in Life Sciences, Physics, Chemistry, and Earth Sciences are presented with increasing levels of complexity from one grade level to another in spiral progression, thus paving the way to a deeper understanding of core concepts. The integration across science topics and other disciplines will lead to a meaningful understanding of concepts and its application to real-life situations (Deped Science Curriculum, 2016). 
Sadly, in a study about Science as a subject, it suggests that while there have been some positive changes, there are still many students who indicate that the science they experience in secondary school is irrelevant to their everyday life and to their future. It seems that the curiosity and wonder one would hope is associated with studying science is missing for a large proportion of students. It is clear that further actions need to be undertaken to transform this continuing situation (Danaia, Fitzgerald \& McKinnon, 2013).

Science teachers are challenged to employ better methodologies and activities to make it more interesting. Teaching Science particularly in high school is not that easy because of the more complicated theories. Aside from it, experiments have to be carefully planned and prepared. In laboratories, Science teachers cannot do it alone because experiments may be harmful. To ensure safety, laboratory assistants provide guidance to students in the experiment processes. Preparing, discussing, and doing the experiments are the challenges that Science teachers experience in teaching. A science teacher is considered someone intellectual, a nature lover, and with great interest about the world. It takes a lot of training including involvement in experiments and travel to the most isolated and dangerous places to be able to find more data leading to knowledge that can greatly impact the world. However, teaching Science can be a very challenging task. It is never easy to teach a subject that is always considered difficult though interesting. But with the right curricular program, it will make sense, easy, and more interesting. An article concluded that the re-orientation of the curriculum toward student-centeredness in this case had a positive effect on student performance, learning experience and subject evaluation. In particular, the use of student-centered techniques facilitated a strong social context for learning, and provided students with a common experiential framework from which to explore the technical aspects of the curriculum (Barraket, 2005).

Science education is about teaching and learning that involves students in inquirybased investigations in which they interact with their teachers and peers; establish connections between their current knowledge of science and scientific understandings; apply science concepts to new questions; engage in problem solving, planning, reasoning from evidence, and group discussions; and experience an active approach to learning science (Contant et al., 2018). Teaching Science involves exposure to the world outside the school campus. An exploratory analysis of student attendance at science museums finds that student achievement in science and mathematics is somewhat higher for those students who visited science museums frequently during the school year or summer. The strength of the association with cognitive achievement is sufficiently noteworthy to encourage further analysis of the role of informal activities such as museum attendance on cognitive learning (Suter, 2014).

The teachers play an important role in making Science interesting. If he/she is confident, credible, interested, and enthusiastic, it will make Science an interesting subject. Likewise, when the teacher self-efficacy is high among teachers in science classrooms, the students display good attitude, better motivation and achievement in science. It is concluded that good impartation of science knowledge on the part of the teacher self-efficacy; along with student's interest and motivation in the subject and the display of positive attitude as earlier pointed out, are influential factors which when combine together are suggested to lead to better academic achievement in science education in secondary and high schools. We posit that the findings of this study will provide the basis for future research on this topic of growing scholarly and practical importance. (Bal-Taştan et al., 2018). 
Aside from self-efficacy, a close teaching and learning relationship with students also works in making Science exciting and very interesting. A study revealed that teachers with strongly student-centered practices tended to exhibit a more pronounced need to create learning opportunities with technology as a base for enhancing 21 st century skills in students. Teachers indicated that external barriers do exist that impact technology integration, such as a lack of in-service training, a lack of available technology, and restricted curriculum, but that overcoming internal barriers, including personal investment in technology, attitude towards technology, and peer support, were a bigger indicator of success. Recommendations are made for restructuring professional development on strategies for contextualizing technology integration in the classroom. Teachers not only know the science content of the subjects they teach to these students. Teachers understand their students enough to reconstruct content knowledge and utilize teaching methods that will make the subject matter accessible to these younger learners. Furthermore, they understand and are familiar with knowledge gaps and preconceptions students bring to science class, and implement differentiated instructional strategies to help students learn. Science teachers also have knowledge of science curriculum choices and resources, and apply technological developments to enhance student learning (Hassard \& Dias, 2013).

Aside from these factors in teaching Science, studies also found out that the use of technology has a positive effect to students. One study suggest that flipped instruction had a positive effect student achievement, with effect sizes ranging from +0.16 to +0.44 . In addition, some students reported that they preferred watching video lectures outside of class and appreciated more active approaches to learning (Leo \& Puzio, 2016). Another study confirmed that teaching science subjects with technology increased the student's interest in the learning process and improved the student's achievement scores and also helped the students to do their homework more easily compared to the traditional teaching methods (Nawzad, \& Said, 2018).

For teachers and students, Science is both classroom and laboratory work. Through various methodologies and activities, Science becomes interesting and engaging. Students are amazed on scientific theories, findings, discoveries, and latest developments in the different branches of Science. In the laboratories, new things unfold right before their eyes. Amazing but challenging, Science continues to trigger the interests of students. Teaching and learning Science happen in the classrooms, laboratories, home, and sometimes in outdoor activities like field trips.

A private sectarian school in Manila which offers dual curricula (academic and technical) in the junior high school department gives importance to Science. Aside from having technologically-equipped classrooms and laboratories, Science teachers are highly engaged in the use of technology in teaching. Laboratory assistants provide support and guidance to students in the conduct of experiments. Every week, Science classes are held for five hours which include laboratory classes. However, when Covid-19 became a pandemic, it put to stop almost everything that people normally do like going to school. In the Philippines, classes were suspended on March 10 until it was decided that the remaining school days be carried through online modality. It was eventually decided by the government that there will be no face-to-face classes until a vaccine has been created. The school administrators decided to minimize the requirements which will be sufficient for the last term. Students received communication from school administrators and teachers through different ways like messenger, email, mobile phones, and landline phones. 
In particular, the Covid-19 pandemic has forced Science teachers to become more creative, resourceful, and innovative. Few studies have suggested what can be done in teaching Science via online modality. A study showed that in getting a biology course online, it is recommended an incremental approach, beginning with a basic set of teaching and learning tools to provide content suited to the classes and the objectives of the course. The extent to which hands-on practical activities are included will vary depending on the nature and purpose of the course. There are several ways in which to incorporate such activities if they are considered appropriate. The basic online biology course can be augmented and developed over time, as the course designer gains confidence and discovers useful and relevant materials. There is scope to tailor the online biology course so that it is highly student centered, with loops and links to suit students who struggle with particular aspects of the course, and other loops and links to extend those who move through the basic content easily. Links may take students outside the LMS to relevant sites, apps, and social media tools, many of which are available to course designers at no cost, but care should be taken to ensure that such additions augment, rather than distract from, the broader aims of the course. The online course is never complete, and the course designer has unlimited opportunities to refine the style, presentation, and the internet has been accessed during an examination. Web-based video was recently reported as being utilized as an assessment tool for student performance in organic chemistry. Students made video responses to specific questions as part of the assessment process and were required to utilize a molecular modeling kit. The method of assessment allowed the instructor to see a student's higher order thinking, and the authors concluded that it appeared to be a viable additional tool for grading student performance. The internet opens up many possibilities for online learning opportunities. Recent innovations include a game-based approach to a physical chemistry course, multiplayer games, and a gaming program to resolve protein structures that have eluded researchers. The latter gaming program can be utilized as a problem-based learning assignment for the understanding of protein folding, interactions, and structure and allows student contributions to significant research. The ability to work on real research problems significantly increased student interest in the assignment (Moore, 2016).

Regarding the curriculum for the new normal, a study pointed out that a curriculum goal that must be emphasized in the new normal curriculum is to develop preparedness competencies among the learners. When it comes to curriculum content, there are challenges to whether to integrate or reduce. On the other hand, instructional approaches mostly shifting to online modality should be considered in the light of different factors. As regards instructional evaluation, some concerns related to the assessment of learning present cogent reminders for educators (Chapay, 2020).

In another study, it revealed that teacher training is important for this new modality in teaching and learning. In order to instill the awareness and competencies on virtual teaching among teachers, seminars on virtual teaching development and management may be conducted in series covering topics related to development, operations, delivery, maintenance, repair, administration and security. The training may start with technical staff, who will assist faculty members in implementing virtual teaching in their respective classes. Likewise, educational leaders may venture on training teachers on how to convert their instructional materials to an electronic format as well as on the familiarity with the different functions and features of e-learning platforms including how to facilitate learning and support learners in a particular learning platform. As regards the implementation of virtual teaching in the education sector under the "new normal", more 
of the teacher factors are yet to be explored, hence it will continue to get the attention of scholars, academicians, curriculum developers and educational leaders in implementing educational reforms in response to the changing societies (Dela Rama et al, 2020).

At the end of school year 2019-2020, the junior high school department met, discussed, planned, and prepared on its undertakings for school year 2020-2021 which led to the creation of a learning continuity plan. With the limitation of having no face-toface classes, each subject area was asked to discuss and prepare the curriculum, activities, and assessment based on the policies issued by the Department of Education on online learning. Since the students have the technological resources and capability, synchronous and asynchronous classes will be conducted through online modality. Two hours are allotted for Science synchronous classes and another two hours for asynchronous classes (consultation periods). Aside from the technical subjects (which includes technical laboratory or shopwork) that junior high school students have to take, Science is one of the academic subjects affected because it involves laboratory classes. It is a perplexing thought on how laboratory work will be done virtually by the teachers and students.

Online teaching may pose some serious problems. Thus, some approaches must be considered. In a study, it revealed that educators need to understand the approach to learning in the new normal era, so they can carry out learning while still avoiding Covid19 exposure. The approach that educators can use is to use an online and offline system approach. Online can be used if the conditions in the area where the education is carried out have internet access, and can be reached well by educators and students. The offline approach can also be applied especially in areas that do not have internet access, because this learning is offline or outside the network. In certain situations educators can also apply by combining the two approaches, taking into account the things that are considered important in the implementation of learning and the achievement of learning objectives (Mertayasa \& Indraningsih, 2020). In another study, it pointed out it is important to review online learning content. Online teaching is completely different once the teacher and students are inside the virtual classroom. Redesigning the course of the study is necessary to suit the online learning platform.

Classes for school year 2020-2021 in this private sectarian school opened last August 24,2020 and term 1 ended last November 6, 2020. Since no school has ever done a completely no face-to-face classes particularly in Science, it is interesting to find out the experiences of the Science teachers in terms of their preparation, teaching engagement, and challenges in online teaching. This study aims to find out the preparations that Science teachers did in terms of curriculum, methodology, instructional materials, and assessment. It also identified the challenges, initiatives, and opportunities in online teaching and learning that Science teachers experienced and realized. Through this study, issues and concerns will be addressed through the initiatives that the Science teachers will identify and the opportunities that they see in teaching through online modality. The online teaching and learning of Science will be enhanced through the experiences and inputs of the Science teachers.

\section{METHOD}

To understand the experiences of the junior high school Science teachers in online learning modality which is considered a global phenomenon, phenomenological method is used in this study. Phenomenology is an approach to qualitative research that focuses on the commonality of a lived experience within a particular group. The fundamental goal 
of the approach is to arrive at a description of the nature of the particular phenomenon (Creswell, 2013). Since school year 2020-2021 started, the science teachers were observed, interviewed informally, and met as one area. After one term or three months of teaching Science through online modality, they were interviewed about their experiences in this historical modality in teaching and learning. Five junior high school Science teachers and two academic heads participated in this study. They have no experience in teaching Science through online modality even in a flexible learning delivery. The participants are not under the supervision of the researcher.

Experts in educational management, and curriculum and instruction were asked to validate the interview questions. The questions were: (1) Having learned that school year 2020-2021 will open, how did you prepare for online teaching? (2) What did you do with the Science curriculum or lessons? (3) What methodologies did you use in Term 1? (4) How did you prepare the instructional materials? (5) How did you conduct the assessments? (6) After Term 1, what do you consider as the top two challenges in teaching Science online? (7) After Term 1, what initiatives can you take to make the online teaching of Science more interesting and engaging? (8) What do you see as opportunities in teaching Science through online modality?

To analyze the data gathered in the study, coding was used by the researchers. In coding, the researcher organizes data collected into segments and assigns a word or phrase to them as labels (Creswell, 2014). The researchers sought the permission of the principal and learning area head before conducting the study. The purpose of the study was discussed to the academic heads and Science teachers. It was made clear that their responses will not affect their status in school and will be used to enhance the online teaching and learning of Science.

\section{RESULT AND DISCUSSION}

The new normal in teaching and learning made all stakeholders imagine on what will happen in education after school year 2020-2021. Since everything is so fluid and the unexpected may come, it is better to be prepared by reflecting on the everyday experiences of teachers. The experiences of the junior high school Science teachers in online teaching after one term or three months of teaching will enable them to understand the issues and concerns, and identify initiatives to enhance online teaching.

In terms of preparation, the Science teachers just like other teachers had to prepare for the unknown. Upon learning that school year 2020-2021 will open, the Science teachers did personal preparations while waiting for the directives of the Department of Education (DepEd) and the school administration. Their personal preparations focused on two areas namely professional development and technology resources enhancement. In a study on preparation for online learning for school year 2020-2021, it revealed that three core themes related namely gathering resources and establishing practices, profiling learners, and capacity building for continuous learning and development. Preparation helps teachers to plan relevant course of actions prior to the implementation of distance learning. This manages teachers to equip themselves with sufficient knowledge and skills, attending the needs and understanding the status of learners, and acquiring relevant materials and resources (De Villa \& Manalo, 2020). 


\section{Professional Development}

Believing that they need to equip themselves with knowledge and skills in online teaching, they attended webinars, read articles, and studied online tutorials about Science, student discipline, conducting online classes, and using different online platforms. One participant shared:

"I attended webinars on how to conduct online teaching and learned from the things that I did during bridging program before the actual start of online classes."

Another participant said:

"I familiarized myself in different online teaching platforms like zoom and google classroom."

\section{Technology Resources Enhancement}

Since the school will hold synchronous classes, they ensured that their internet will be stable by subscribing to internet providers for home installation. They also upgraded their laptops by installing better hardware and necessary software. Some bought new laptops, headphones, cameras, pen tablet, and ring light. A participant said:

"First, I made sure that my internet connection at home is strong enough to conduct online classes. I bought some equipment needed for online meetings such as web camera and headphones."

When DepEd released its plans and preparation, the school administration immediately discussed the challenges, issues and concerns, and strengths of the institution for online instructional delivery. After the learning continuity plan has been created, the different learning areas in the junior high school met and planned for the upcoming school year. The junior high school Science teachers discussed their preparations in terms of curriculum, methodology, instructional materials, and assessment. The following is the discussion of the results of their preparations in terms of the following:

\section{Curriculum}

When Philippine President Rodrigo Duterte announced that school year 2020-2021 will open through flexible learning modality (online and other alternatives) and no faceto-face classes until a vaccine has been created, DepEd mobilized and prepared immediately. One of the major preparations was on curriculum. It led to the creation of the Most Essential Learning Competencies (MELCs). Guided by this directive, the Science teachers prepared the curriculum by revising and condensing the curriculum by including the non-negotiable competencies. Based on the guidelines given by the school, they modified the curriculum by identifying only the most essential lessons. A participant pointed out: 
"I also considered the things that we discuss in our vertical articulation last school year and remove some topics that are also being discussed in other subject/technical area (e.g. electromagnetism)."

Another participant shared:

"I read the science curriculum in advance before the term started and thought of possible activities to make about the lessons."

DepEd issued the Guidelines on the Use of the Most Essential Learning Competencies (MELCs), and presented its rationale. Being seriously affected by the Covid-19 pandemic, it will not be unfazed in continuing education by ensuring the welfare of more than 27 million learners in the basic education which requires indomitable commitment especially amidst this crisis. If learning stops, we will lose human capital.' Thus, meeting the needs of the most vulnerable populations in these times is essential in achieving SDG4 (UNESCO, 2017). The Department echoes UNESCO's belief that educational quality, access, and system strengthening cannot be compromised in times of crisis (UNESCO, 2017) and doing the opposite will negatively affect human capital. Consequently, DepEd's Bureau of Curriculum Development ensures that learning standards are relevant and flexible to address the complex, disruptive, volatile, and ambiguous impact of Covid-19 in the Philippines particularly in the basic education sector.

Working on the said premise, the Department hereby releases the Most Essential Learning Competencies (MELCs) to be used nationwide by field implementers and private schools for SY 2020-2021 only. The release of the MELCs is not just a response to addressing the challenges of the current pandemic but is also part of the Department's long-term response to the call of SDG 4 to develop resilient education systems, most especially during emergencies. Thus, it can be used under certain circumstances as a mechanism to ensure education continuity (curriculum dimension). However, releasing the MELCs does not downplay the standards set by the K to 12 curriculum guides. Rather, these serve as guide to teachers as they address the instructional needs of learners while ensuring that curriculum standards are maintained and achieved. The content and performance standards are indicated in the attached documents for field implementers to recognize that the MELCs are anchored on the prescribed standards. Despite the challenges, if online education is well-designed, could just be as effective as face-to-face instruction with an emphasis on the design of the learning experience, the quality of the content, and the engagement of learners (Callo \& Yazon, 2020).

\section{Methodology}

Engaging students in learning Science is always considered a challenge by teachers. Though Science may be perceived as difficult, it can be made interesting by teachers by applying the appropriate teaching methodology and designing activities. However, the online modality may prove to be more challenging because of its limitations. From their classroom experience and readings, they identified face-to-face methodologies that can applied in online teaching for a start. They perceived that inquiry-based learning 
incorporated with 5E's approach, student-centered approach, lecture and simple experiments, motivational activities, and feedbacking would be the most appropriate methodologies for online learning. Based on their experience in term 1 , the aforementioned methodologies proved to be suitable. A participant said:

"I used inquiry-based learning and I incorporated 5E's approach. Inquiry-based is appropriate on this type of setting to ensure their participation during online learning by asking questions to them and through investigating and critiquing, they can come up with their own answers. I also group them to collaborate with each other and discuss a particular topic that they need to present."

In terms of giving feedback, a participant shared:
"By providing on going feedback with the students and at the same time with the teachers in the area, using different learning tools that will equip the students need especially in a home- based science experiment."

All teachers agreed that keeping it simple through motivational activities and student participation will keep the students engaged and interested in the discussion. Though lecture can be the normal methodology to do, it is about making the students involved in the discussion.

\section{Instructional Materials}

The advent of technology brought the preparation of instructional materials to a different level. From the usual chalk and blackboard including flashcards, maps, and posters, technology-based instructional materials were created that made teaching and learning more visual and enticing. But the preparation of technology-based instructional materials may not be easy as it seems, a study on the integration of technology in teaching Science and Math concluded that teachers have the knowledge and skills in using technology for teaching and learning, but they need time to plan and prepare technologybased instructional materials. Also, they want to update their knowledge and skills in various educational technologies including social media and MS Excel as they integrate them in teaching and learning. Teaching and learning will become more creative, interesting, and engaging if technology integration is extensively implemented (Arrieta, 2020). With online learning as the new normal in education, preparation of technologybased instructional materials may become more challenging because of the many platforms found in the internet that can be used.

To respond to the new environment in teaching and learning, Science teachers said that they prepared and used interactive classroom discussion aided by the different applications, multi-media presentations, e-books, youtube videos, google slides, article reviews (published in the internet) digital pen and tablet, and MS whiteboard. They added that these instructional materials are available in the internet and can be explored. A participant pointed out: 


\begin{abstract}
"Since all junior high school Science teachers are millennials and digital natives, it was easy for us to adapt to the challenges in preparing and using technology-based instructional materials like video-creation and internet-based applications."
\end{abstract}

With technology-based instructional materials going to a higher level brought about by the online teaching and learning in the new normal in education, it is expected that upcoming literatures on the use of technology in teaching will come out. This is not new anymore. In fact, when the use of technology in teaching and learning was on its initial stages particularly with the introduction of the Technological Pedagogical Content Knowledge (TPACK), there were sustained efforts to continue monitoring the challenges of teaching with technology. As technology develops, it somehow makes teaching with technology challenging. In their work, the word - technologyll applies equally to analog and digital as well as to new and old technologies. As a matter of practical significance, however, most of the technologies under consideration in the current literature are newer and digital and have some inherent properties that make applying them in straightforward ways difficult (Koehler, 2012).

\title{
Assessments
}

One of the concerns raised when the school administration was discussing the learning continuity plan for school year 2020-2021 is academic dishonesty. Online learning is certainly more prone to cheating because of the many limitations it presents. Students will be tempted to cheat since there is no teacher personally proctoring the test. Posing as a challenge to all teachers, the Science teachers prepared and conducted assessments by giving more practical questions supported by scientific principles, observation, using the learning management system of the school called Genyo, google forms, and asking the students to make handwritten assignments. Since asking the students to submit assignments or requirements that are handwritten, a participant shared:

\begin{abstract}
"Some of the assignments or seatwork of my students are handwritten so they just write their answers in a sheet of paper then they will take a picture of their output and send it to their respective google classrooms."
\end{abstract}

The participants agreed that the assessment must enhance the application skills of the students. Giving of multiple choice questions is prone to cheating and the use of the learning management system helped a lot in giving assessments. Though challenging, they made it a point to monitor consistently their students in assessments through close observation. A study on preventing cheating in online engagement said that dealing with the risks of plagiarism and cheating in online courses is more challenging than in face-toface courses, but we have tried to show that online programs have both opportunities and challenges. Faculty and administrators have to be proactive in thinking about course and program design, as well as simply deciding what compromises to make when migrating existing pedagogy and assessment schemes. The study further suggested that: (1) Students be given enough resources (reviews, etc.) that they are not tempted to cheat. (2) Explain to students often that they do not need to cheat or plagiarize to do well in your class. (3) Give them enough difficulty in assignments to build confidence in their abilities 
throughout the semester. (4) Prosecute each and every instance of academic dishonesty and encourage your peers to do the same. (5) Discuss penalties and the university process in the syllabus and the test instructions. (6) Make sure students understand that cheating will be prosecuted. (7) Give students explicit incentives to report cheating by others as required by the student code of conduct at most universities. (8) Have a very explicit statement in your syllabus that clearly articulates the penalty for cheating or plagiarism in your class. (9) Have students complete individual honor pledges for the class and/or each assignment (Michael \& Williams, 2013).

\title{
Challenges in Online Teaching and Learning
}

Even before the start of school year 2020-2021, teachers have anticipated the real challenges in new normal in teaching and learning like academic dishonesty, attendance, internet connection, and participation. However, it is different when one experienced and encountered them. After one term or three months in online learning, expected and unexpected challenges surfaced. The junior high school Science teachers have encountered challenges that can be addressed next term. However, there are some challenges that can only be resolved in the real classroom. They shared that support of other stakeholders, student discipline, delivery and execution of learning tasks, limited time for the implementation of the competencies, student participation, and topics for real laboratory work are the main challenges they encountered. A participant clearly pointed out:

"The first challenge is, how can we show to our students the application and uses of some lessons since we cannot conduct any laboratory experiments. The second challenge is the implementation of all competencies on each year level per term since we have only two meetings per week unlike in face-to-face setting wherein we meet four times a week."

On laboratory work particularly topics that are for real laboratory, a participant lamented:

\begin{abstract}
"There are some topics in Science that will be appreciated if done in a real Laboratory set-up. It is impossible for these topics to be discussed and done at home. There are risks involved and materials that are not available to students."
\end{abstract}

The Covid-19 pandemic has presented a lot of challenges to teachers and students in teaching and learning. It can be drawn that the real classroom or laboratory cannot be replaced by the virtual classroom. Student discipline remains a challenge because they are not physically present and their parents are monitoring them. There may be cases that parents are tolerating their children's wrong doings by letting them commit academic dishonesty. Regarding student participation, teachers can only do as much as they can in engaging them in recitation. They can turn off their camera and microphones during online learning and pretend that they are listening. Stakeholders may not show strong support consistently in this new normal. An evaluation every one term or quarter can be done since the situation is so fluid. In a study conducted about the challenges of online learning during this pandemic, it explained that this terrible time of fate has taught us that 
everything is unpredictable and we need to be ready to face challenges. Although this outbreak did not give us much time to plan we should take a lesson from this that planning is the key. We should plan everything, no matter if plan A fails, we should have plan B ready. This can only be done if we do scenario planning. There is a need to prioritize all the critical and challenging situations which may occur and plan accordingly. This pandemic has also taught us that students must possess certain skills such as skills of problem-solving, critical thinking, and most importantly adaptability to survive the crisis. Educational institutions must build resilience in their systems to ensure and prioritize the presence of these skills in their students (Dhawan, 2020).

\section{Initiatives for a Better Online Teaching and Learning}

The preparation for the online teaching and learning modality may have provided a boost and confidence to Science teachers. With the challenges encountered, new ideas and realizations are drawn from these experiences paving the way for initiatives to be taken in the online modality that will assist in enhancing teaching and learning in the remaining months of school year 2020-2021. They said that providing interactive games, creativity in implementing the 5E's, engaging in more hands-on activities, lessening the activities and vlogging as initiatives in teaching Science. A participant shared:

"I thought that I am not good in vlogging. I tried doing it and used it to engage my students in class discussion. To my surprise, they liked it and I decided to continue vlogging. This is what I can do even after this pandemic."

Believing that one's creativity will be developed, a participant excitedly said:
"I will try constructivism approach wherein students will construct their own understanding of lessons based on their schema, drills or tasks and experiences. Also, I will include more online experiments in the lesson-discussion because their creativity works well when we do it."

To engage the students more in Science, a participant shared:

\section{"By providing interactive games in Science via online, I expect that it will engage students to participate more in class."}

Initiatives have to be taken to make education happen in a better way. Online education which can be considered distance learning will provide new initiatives based on experiences and challenges. In the education sector, it has enormous potential to help organizations address issues of access to learning, quality of the teaching learning process and management of education systems. In order to ensure the quality of education, the distance education institutions must be careful about the use of proper technologies and media. We have to think about the uses of media and technology in regard to appropriateness and acceptability in the society as well as on the ability of the institution offering the program. The socio-economic and cultural background of a person influences their ability to learn from different media technology. In order to evolve a fully articulated 
education system and for the success of distance education and ODL must be seen as an equally responsible medium complementing the formal learning system. Teaching organizations are adopting ICT, especially the computers, World Wide Web, teleconferencing and educational television because of their cost effectiveness, access and flexibilities of choices. Effective combination of media and technology is necessary for assuring effectiveness of the open and distance learning system (Team, 2020). In another study, it found out that teacher initiatives are important like collaboration, networking, social media communication and other digital literacy practices, including the out-ofschool digital literacy practices. These are teacher initiatives leading to the utilization of digital connection platforms for socialization and teaching and learning. In addition to dividends of connectivism, visual communication and cyber linguistics have become critical for digital-age learners. Teacher initiatives are a crucial part of adaptive resilience, as teachers need to adjust to shortages of digital technology resources and connectivity (Rwodzi, 2018).

\title{
Opportunities in Online Teaching and Learning
}

Many have been said about getting through these trying times and restarting our lives. Indeed, there is a silver lining in this health crisis most especially in education. Despite the limitations and challenges brought about by Covid-19 pandemic, education continued and found an ally in online learning and teaching. The junior high school Science teachers have seen creativity in teaching with no laboratory, discovering new things on their (students) own, exploring more ways to teach science online, using online published researches as instructional materials, realizing more opportunities for improvement, and becoming more confident in front of the camera. A participant who tried vlogging said:

\section{"I see vlogging as an opportunity and it makes me more excited. I think I'm slowly becoming a vlogger rather than a teacher."}

Another participant who saw how his students become more engaged in Science shared:

\author{
"Students are more interested to discover new things with their \\ own. Especially if I give them activities that they need to make \\ different models/realia related to our topic (e.g. Seafloor \\ spreading model)"
}

Science teachers consider these opportunities as making them better Science teachers who can adapt to the challenges of the times. Trying new things may not sit well to many teachers but the present situation will force them to take the road less traveled. As they reach the end of the road, they will find out that there are still a lot of opportunities to make online teaching and learning better. It may prepare them when the world returns to a better normal world. A study found out that online learning generally has a lot of opportunities available but this time of crisis will allow online learning to boom as most academic institutions have switched to this model. Now, academic institutions can grab this opportunity by making their teachers teach and students learn via online methodology. The people have always been complacent and never tried some new modes of learning. This crisis will be a new phase for online learning and will allow people to 
look at the fruitful side of e-learning technologies. This is the time when there is a lot of scope in bringing out surprising innovations and digital developments. Already, EdTech companies are doing their bit by helping us fighting the pandemic and not letting learning to be put at a halt. Teachers can practice technology and can design various flexible programs for students' better understanding. The usage of online learning will test both the educator and learners. It will enhance problem-solving skills, critical thinking abilities, and adaptability among the students. In this critical situation, users of any age can access the online tools and reap the benefits of time and location flexibility associated with online learning. Teachers can develop innovative pedagogical approaches in this panicky situation, now also termed as Panicgogy. EdTech Start-ups have plenty of opportunities to bring about radical transformations in nearly all the aspects associated with education ranging from, teaching, learning, evaluation, assessment, results, certification, degrees, and so on. Also, increasing market demand for e-learning is an amazing opportunity for EdTech start-ups to bring technological disruption in the education sector (Dhawan, 2020).

Bringing synchronous learning online presents several challenges to both instructors and students, yet, it provides learning opportunities for instructors to rethink how to bring forward some of the lessons from online learning back to physical classrooms. This is taken particularly in view of the various technological advancements and societal shifts that, ironically, enables us to transit from offline to online learning with minimum disruption in such trying times (Tan \& Chen, 2020).

Even before this Covid-19 pandemic came, there were already initiatives taken on teaching and learning through online modality. It is called blended learning. It was anticipated that his may be the future of education. With the pandemic forcing everyone to do online education, it seems that blended learning is the harbinger of substantial change in higher education and will become equally impactful in K-12 schooling and industrial training. Blended learning, because of its flexibility, allows us to maximize many positive education functions. This may be the new normal in the post Covid-19 pandemic (Dziuban et al, 2018).

\section{CONCLUSION}

The study found out that Science teachers prepared well for online teaching and learning despite not knowing the path to be traversed. They prepared professionally by attending webinars, studying various online platforms, and identifying non-negotiable competencies. On the other hand, they did personal preparations by strengthening their technological resources and capabilities. Their internet connection must be strengthened and laptops must be upgraded to meet the requirements of virtual teaching and learning. In terms of curriculum, it was modified and only the most essential learning competencies will be covered. Methodologies like student-centered approach, inquiry-based learning, feedbacking, and creativity were applied. Instructional materials were enhanced by using new online platforms and applications, creating vlogs, and better multimedia presentations. Assessments were done through the learning management system (Genyo), google forms, and even asking the students to make handwritten assignments. Regarding challenges in online teaching and learning, they said that support of other stakeholders, student discipline, delivery and execution of learning tasks, limited time for the implementation of the competencies, student participation, and topics for real laboratory work are the main challenges. To address the challenges, they said that providing 
interactive games, creativity in implementing the 5E's, engaging in more hands-on activities, lessening the activities and vlogging are initiatives that can be taken by the Science teachers. Despite the difficult situation in virtual teaching and learning, they see opportunities like creativity in teaching with no laboratory, discovering new things on their (students) own, exploring more ways to teach science online, using online published researches as instructional materials, realizing more opportunities for improvement, and becoming more confident in front of the camera.

Based on the findings, it can be concluded that Science teachers find that their preparations greatly helped them in the new normal in teaching. However, despite the preparations, new challenges emerged like making students more engaged in learning, new activities, and doing laboratory work online. The challenges can be overcome by taking initiatives and doing more creative activities that are doable online. Science teachers also see a silver lining in the new normal by becoming more updated and continuously engaging in the new developments in Science for there are better things to come. Moreover, they see that their experiences in the new normal will make them better educators particularly as Science teachers when they go back to the real classroom and adapt to the incoming new normal in education after the Covid-19 pandemic.

\section{REFERENCES}

Arrieta, G. S. (2020). Assessment of the ict integration in teaching math and science in high school: Basis for an ict integration program. Jurnal Pendidikan MIPA, 21(1), 95-108.

Bal-Taştan, S., Davoudi, S. M. M., Masalimova, A. R., Bersanov, A. S., Kurbanov, R. A., Boiarchuk, A. V., \& Pavlushin, A. A. (2018). The impacts of teacher's efficacy and motivation on student's academic achievement in science education among secondary and high school students. Eurasia Journal of Mathematics, Science and Technology Education, 14(6), 2353-2366.

Barraket, J. (2005). Teaching research method using a student-centred approach? Critical reflections on practice. Journal of University Teaching \& Learning Practice, 2(2) 65-74.

Cahapay, M. B. (2020). Rethinking education in the new normal post Covid-19 era: A curriculum studies perspective. Aquademia, 4(2), 1-5.

Callo, E. C., \& Yazon, A. D. (2020). Exploring the factors influencing the readiness of faculty and students on online teaching and learning as an alternative delivery mode for the new normal. Universal Journal of Educational Research, 8(8), 3509-3518.

Contant, T. L., Tweed, A. L., Bass, J. E., \& Carin, A. A. (2018). Teaching inquiry through inquiry-based instruction. New York, NY: Pearson.

Creswell, J. W. (2013). Research Design: Qualitative Approach, Quantitative and Mixed. Yogyakarta: Student Library.

Danaia, L., Fitzgerald, M., \& McKinnon, D. (2013). Students' perceptions of high school science: What has changed over the last decade? Research in Science Education, 43(4), 1501-1515.

Department of Education. (2016). K to 12 Curriculum Guide Science (Grade 3 to Grade 10). https://www.deped.gov.ph/wp-content/uploads/2019/01/Science-CG_withtagged-sci-equipment_revised.pdf

Department of Education. (2020). Guidelines on the use of the most essential learning competencies (MELCs). https://commons.deped.gov.ph/MELCS-Guidelines.pdf 
Dhawan, S. (2020). Online learning: A Panacea in the time of Covid-19 Crisis. Journal of Educational Technology Systems, 49(1), 5-22.

De la Rama, J., Sabasales, M., Antonio, A., Ricohermoso, C., Torres, J., Devanadera, A., \& Alieto, E. (2020). Virtual teaching as the 'new norm': Analyzing science teachers' attitude toward online teaching, technological competence and access. International Journal of Advanced Science and Technology, 29(7), 12705-12715.

De Villa, J. A., \& Manalo, F. K. B. (2020). Secondary teachers' preparation, challenges, and coping mechanism in the pre-implementation of distance learning in the new normal. IOER International Multidisciplinary Research Journal, 2(3), 144-154.

Dziuban, C., Graham, C. R., Moskal, P. D., Norberg, A., \& Sicilia, N. (2018). Blended learning: The new normal and emerging technologies. International Journal of Educational Technology in Higher Education, 15(1). 1-16.

Hassard, J., \& Dias, M. (2013). The art of teaching science: Inquiry and innovation in middle school and high school. Routledge.

Koehler, M. (2012). TPACK Explained [Webpage]. TPACK ORG. http://www.tpack.org/

Leo, J., \& Puzio, K. (2016). Flipped instruction in a high school science classroom. Journal of Science Education and Technology, 25(5), 775-781.

Michael, T. B., \& Williams, M. A. (2013). Student equity: Discouraging cheating in online courses. Administrative Issues Journal, 3(2), 6.

Moore, M. G. (2016). Teaching science online: practical guidance for effective instruction and lab work. Stylus Publishing, LLC.

Nawzad, L., Rahim, D., \& Said, K. (2018). The effectiveness of technology for improving the teaching of natural science subjects. Indonesian Journal of Curriculum and Educational Technology Studies, 6(1), 15-21.

Ruggiero, D., \& Mong, C. J. (2015). The teacher technology integration experience: Practice and reflection in the classroom. Journal of Information Technology Education Research, 14, 161-178.

Rwodzi, C. (2018). Exploring teacher initiatives on teaching digital literacies in English (Doctoral dissertation, University of Pretoria).

Safaah, E. S., Muslim, M., \& Liliawati, W. (2017). Teaching science process skills by using the 5-stage learning cycle in junior high school. Journal of Physics: Conference Series, 895, 1-6.

Simamora, R. M. (2020). The challenges of online learning during the Covid-19 pandemic: An essay analysis of performing arts education students. Studies in Learning and Teaching, 1(2), 86-103.

Suter, L. E. (2014). Visiting science museums during middle and high school: A longitudinal analysis of student performance in science. Science Education, 98(5), 815-839.

Tan, D. Y., \& Chen, J. M. (2020). Bringing physical physics classroom online-challenges of online teaching in the new normal. arXiv preprint arXiv:2009.02705.

Team, Y. (2020). Key initiatives in education. Innovation in Education, 64(2), 35.

The University of Texas at Arlington Academic Partnerships. (2017). Importance of Science Education in Schools. Retrieved from https://academicpartnerships.uta.edu/ articles/education/importance-of-science-education.aspx. 